\title{
The need to establish and enforce the liability of refugee- generating entities: addressing the normative lacuna in the intersection between International Refugee Law and the Law of International Responsibility
}

\author{
Yi Chao* \\ Doctoral (DCL) candidate, McGill University Faculty of Law \\ yi.chao@mail.mcgill.ca
}

\begin{abstract}
With the recent refugee 'crisis', the liability for refugee-generating once again becomes a matter of concern in international law. When situations in a few countries are generating the majority of the global refugee population, it is pertinent to ask 'who are generating refugees in these countries,' do they bear liability of any kind under international law for generating refugees,' and 'if yes, are there legal mechanisms in place to enforce the liability'. This paper aims to address these questions.

Despite scholarly endeavors dated back to as early as 1939, positive international law in its current shape still seems unable to establish the liability of refugee-generating entities. No treaty spells out such liability, and it seems hard to argue that such liability exists in customary international law. This highlights a normative lacuna in the intersection between International Refugee Law and the Law of International Responsibility, as neither the framework of State responsibility nor that of transboundary harm can be applied seamlessly to refugee-generating situations.

To address this normative lacuna, this paper argues for a new way to establish international liability of refugee-generating entities based on Louis Henkin's theory of 'constitutional international law'. After defining 'refugee-generating entities' by reference to Article 1(A)(2) of the 1951 Convention relating to the Status of Refugees, this paper envisions possible mechanisms under domestic and international law to enforce the liability of refugee-generating entities and appraisals their practicality and desirability.
\end{abstract}

\section{Keywords}

international refugee law, international responsibility, Afghanistan, Somalia, Syria 


\section{Introduction}

Refugee protection poses a unique and pressing challenge to the global community and international law, especially at the present time. According to UNHCR's annual statistical report, there were 19.9 million refugees in the world in 2017. Another 5.4 million Palestinian refugees were registered by the United Nations Relief and Works Agency for Palestine Refugees in the Near East (UNRWA). ${ }^{2}$

As UNHCR pointed out in its 2017 statistical report, '[a]ltogether, more than two-thirds (68 per cent) of all refugees worldwide came from just five countries.' This highlights a striking feature of today's refugee problems, i.e. situations in a few countries are generating the majority of the global refugee population. As Table $1^{4}$ illustrates, every year from 2010 to 2017, numbers of refugees coming from the top three to five origin countries already constituted the majority of global refugee population.

Table 1: Numbers of refugees from top origin countries and their percentage in annual worldwide refugee population: 2010-2017

\begin{tabular}{|c|c|c|c|c|c|c|c|c|}
\hline Year & $\begin{array}{l}\text { Worldwide } \\
\text { refugee }\end{array}$ & \multicolumn{7}{|c|}{$\begin{array}{l}\text { Numbers of refugees coming from top origin countries and their percentage in } \\
\text { the worldwide refugee population }\end{array}$} \\
\hline 2017 & 19.94 & $\begin{array}{l}\text { Syria }(6.31, \\
32 \%)\end{array}$ & \multicolumn{3}{|c|}{ Afghanistan $(2.62,13 \%)$} & \multicolumn{2}{|c|}{ South Sudan $(2.44,12 \%)$} & $\begin{array}{l}\text { Combined } \\
(11.37,57 \%)\end{array}$ \\
\hline 2016 & 17.19 & $\begin{array}{l}\text { Syria }(5.52, \\
32 \%)\end{array}$ & \multicolumn{3}{|c|}{ Afghanistan $(2.50,15 \%)$} & \multicolumn{2}{|c|}{ South Sudan $(1.44,8 \%)$} & $\begin{array}{l}\text { Combined } \\
(9.46,55 \%)\end{array}$ \\
\hline 2015 & 16.12 & $\begin{array}{l}\text { Syria }(4.87, \\
30 \%)\end{array}$ & \multicolumn{3}{|c|}{ Afghanistan $(2.67,17 \%)$} & \multicolumn{2}{|c|}{ Somalia $(1.12,7 \%)$} & $\begin{array}{l}\text { Combined } \\
(8.66,54 \%)\end{array}$ \\
\hline 2014 & 14.38 & $\begin{array}{l}\text { Syria }(3.88, \\
27 \%)\end{array}$ & \multicolumn{3}{|c|}{ Afghanistan $(2.59,18 \%)$} & \multicolumn{2}{|c|}{ Somalia $(1.11,8 \%)$} & $\begin{array}{l}\text { Combined } \\
(7.58,53 \%)\end{array}$ \\
\hline 2013 & 11.70 & $\begin{array}{l}\text { Afghanistan } \\
(2.56,22 \%)\end{array}$ & \multicolumn{3}{|c|}{ Syria $(2.47,21 \%)$} & \multicolumn{2}{|c|}{ Somalia $(1.12,10 \%)$} & $\begin{array}{l}\text { Combined } \\
(6.15,53 \%) \\
\end{array}$ \\
\hline 2012 & 10.50 & $\begin{array}{c}\text { Afghanistan } \\
(2.59,25 \%)\end{array}$ & $\begin{array}{c}\text { Somalia } \\
(1.14, \\
11 \%)\end{array}$ & \multicolumn{2}{|c|}{ Iraq $(0.75,7 \%)$} & $\begin{array}{c}\text { Syria } \\
(0.73, \\
7 \%)\end{array}$ & Sudan $(0.57,5 \%)$ & $\begin{array}{l}\text { Combined } \\
(5.78,55 \%)\end{array}$ \\
\hline 2011 & 10.40 & $\begin{array}{l}\text { Afghanistan } \\
(2.66,26 \%)\end{array}$ & \multicolumn{2}{|c|}{$\begin{array}{c}\text { Iraq (1.43, } \\
14 \%)\end{array}$} & $\begin{array}{c}\text { Somalia } \\
(1.08,10 \%)\end{array}$ & \multicolumn{2}{|c|}{ Sudan $(0.50,5 \%)$} & $\begin{array}{l}\text { Combined } \\
(5.67,55 \%)\end{array}$ \\
\hline 2010 & 10.55 & $\begin{array}{l}\text { Afghanistan } \\
(3.05,29 \%)\end{array}$ & \multicolumn{3}{|c|}{ Iraq $(1.68,16 \%)$} & \multicolumn{2}{|c|}{ Somalia $(0.77,7 \%)$} & $\begin{array}{l}\text { Combined } \\
(5.50,52 \%)\end{array}$ \\
\hline
\end{tabular}

In light of this finding, it is natural to ask (1) who is generating the refugees from these countries? (2) whether they bear any liability under international law for generating refugees, and (3) if international liability for generating refugees can be established, are there legal mechanisms in place to enforce it? This paper aims to address these questions.

Queries about the liability of refugee-generating entities (RGEs) under international law are nothing new. As early as 1939, when the law of international responsibility had not developed into legal frameworks as it has today, Sir Robert Jennings demonstrated an attempt to establish State responsibility for creating refugees based on the abuseof-rights doctrine and the sic utere tuo ut alienum non laedas principle. ${ }^{5}$ With developments in the codification of the rules on State responsibility, ${ }^{6}$ some contemporary writers continued to argue for the application of State responsibility to refugee-generating countries, ${ }^{7}$ especially in light of the initiatives for a 'preventive' approach to refugee problems

1 UNHCR, Global Trends: Forced Displacement in 2017 at 2, available at www.unhcr.org/5b27be547.pdf (last visited 24 August 2018). UNHCR's statistics adopt a broad definition of refugees which includes refugees defined under treaties and the UNHCR Statute, individuals granted complementary or temporary protection and people in refugee-like situations, at 61.

$2 \quad$ Ibid at 2.

3 Ibid at 3

$4 \quad$ All the statistics are excerpted from the UNHCR Global Trends reports and calculated by this author.

5 R. Yewdall Jennings, 'Some International Law Aspects of the Refugee Question' (1939) 20 British Yearbook of International Law 98 at $110-114$. 6 The most notable codification is that of the International Law Commission which resulted in the adoption of the Draft Articles on Responsibility of States for Internationally Wrongful Acts.

7 See e.g. Payam Akhavan \& Morten Bergsmo, 'The Application of the Doctrine of State Responsibility to Refugee Creating Countries' (1989) Nordic Journal of International Law 243; Christian Tomuschat, 'State Responsibility and the Country of Origin', in Vera Gowlland-Debbas (ed.), The Problem of Refugees in the Light of Contemporary International Law Issues (Martinus Nijhoff Publishers, 1995) at 59. 
within the United Nations. ${ }^{8}$ One recent reiteration can be found in Guy Goodwin-Gill and Selim Sazak's 2015 article in Foreign Affairs entitled Footing the Bill: Refugee-Creating States' Responsibility to Pay. ${ }^{9}$ Focusing on the Syrian refugee crisis, they argued that 'the State of origin could be held financially liable [...] and subjected to sanctions' for generating refugees and proposed that frozen assets of refugee-generating countries should be used to provide humanitarian assistance to refugees. ${ }^{10}$

Despite scholarly endeavors, however, the liability of RGEs for refugee-generating still does not exist in treaties or customary international law. As commentators point out, international refugee law has been focusing almost exclusively on the responsibility of receiving States since its birth. ${ }^{11}$ No provision in the 1951 Convention relating to the Status of Refugees $^{12}$ ('1951 Convention'), its 1967 Protocol' $^{13}$ or the OAU Convention Governing the Specific Aspects of Refugee Problems in Africa ${ }^{14}$ ('OAU Refugee Convention') addresses RGEs' liability. Due to the lack of widespread State practice and opinio juris, it is also unconvincing to find RGEs' liability in customary international law. As Flavia Giustiniani noted in 2015 , '[p]ractice shows that host States, rather than openly invoking the responsibility of source countries, have found it more practicable to limit their own [responsibility to protect refugees]. ${ }^{15}$

This paper aims to make the following contribution to the discussion of RGEs and their liability. First, this paper emphasises the need to identify RGEs. So far, there is no clear prescription in international law - no norm of international refugee law, international human rights law or international criminal law - to determine who is responsible for refugeegenerating. Although one may intuitively propose that anyone who violates human rights and therefore leads to mass flows of individuals is an RGE, defining RGEs as such can be under inclusive. As analysis in Section 2 will demonstrate, there can be good reasons to identify RGEs in some cases even if the entities in question have not violated international human rights law. Moreover, as Section 3 will show, refugee-generating - i.e. the creation of a 'well-founded fear' of persecution - does not necessarily require an actual breach of international human rights obligations. Therefore, the identification of RGEs is not always clear cut and leaves room for discretion in some circumstances. Such complexities with the identification of RGEs deserve recognition and discussion.

Second, this paper aims to establish the liability of RGEs in international law. Although this topic has been addressed by others, most of the existing literature relies on the law of international responsibility - State responsibility or strict liability in international law - as the legal basis of RGEs' liability. Such an approach, however, is hard to maintain from the perspective of positive law. As Section 3 will demonstrate, there are various legal obstacles to applying State responsibility or strict liability seamlessly to refugee-generating. In other words, the law of international responsibility de lege lata is insufficient to establish RGEs' liability in international law. In order to tackle this problem, this author uses Louis Henkin's theory of 'constitutional international law' to argue for a new way of establishing RGEs' liability.

The lack of liability of RGEs not only demonstrates a normative lacuna in international law but also poses a pressing and fundamental threat to the sustainable functioning of international refugee protection. Because the liability for generating refugees is not established, much less enforced, more and more displacement overflows are being produced from top origin countries while the receiving States become less and less willing to admit asylum seekers into their territory. ${ }^{16}$ If this continues to be the case, the system of international refugee protection will be doomed to collapse.

It has long been noted that the solution to refugee problems should have at least two complementary sides: the 'protection'side that focuses on the receiving States' obligation to protect refugees and the'root cause' side that prevents and alleviates refugee-generating activities in the countries of origin. ${ }^{17}$ The root cause side would address the liability of RGEs. Although there were once some initiatives for a 'preventive' approach to refugee problems within the United Nations ${ }^{18}$ such initiatives did not lead to actual establishment or enforcement of RGEs' liability. Today, international refugee law still only'poses several obligations on third States, but none directly on the country of origin'.19 The current refugee 'crisis' indicates that solely relying on the protection side is far from sufficient to solve refugee problems, and many receiving States have started to show considerable reluctance if not hostility towards receiving refugees and asylum seekers. Therefore, it is no longer an option for international refugee law to solely focus on the receiving States and turn a blind eye to the root causes that generate refugees in the first place.

8 See Akhavan \& Bergsmo, supra note 7 at 248-251; Rainer Hofmann,'Refugee-Generating Policies and the Law of State Responsibility' (1985) 45 Heidelberg Journal of International Law 694 at 695-697.

9 Guy S. Goodwin-Gill \& Selim Can Sazak, Footing the Bill: Refugee-Creating States'Responsibility to Pay, in Foreign Affairs, 29 July 2015 , available at www.foreignaffairs.com/articles/africa/2015-07-29/footing-bill (last visited 23 August 2018).

10 Ibid. See also Selim Can Sazak, 'An Argument for Using Frozen Assets for Humanitarian Assistance in Refugee Situations' (2015) 68 Journal of International Affairs 305.

11 Tomuschat, supra note 7 at 59. See also James C. Hathaway \& Michelle Foster, The Law of Refugee Status, 2nd edn (Cambridge University Press, 2014) at 301 ('refugee law is not concerned with assessing State responsibility').

1228 July 1951, 189 UNTS 150 (entered into force 22 April 1954).

13 Protocol relating to the Status of Refugees, 31 January 1967, 606 UNTS 267 (entered into force 4 October 1967).

1410 September 1969, 1001 UNTS 45 (entered into force 20 June 1974).

15 Flavia Zorzi Giustiniani,'The Obligations of the State of Origin of Refugees: An Appraisal of a Traditionally Neglected Issue'(2015) 30 Connecticut Journal of International Law 171 at 176.

16 Many new tools have been invented by receiving States, especially the developed countries, to prevent asylum seekers from entering their territory, see Thomas Gammeltoft-Hansen \& James C. Hathaway, 'Non-Refoulement in a World of Cooperative Deterrence' (2015) 53 Columbia Journal of Transnational Law 235 at 248-257.

17 See e.g. Akhavan \& Bergsmo, supra note 7 at 243.

18 See ibid at 248-251; Hofmann, supra note 8 at 695-697.

19 Giustiniani, supra note 15 at 173. 
The objective of this paper is to first establish the liability of RGEs in international law and then explore possible mechanisms to enforce it. In order to establish the liability of RGEs, we need to (1) identify who are RGEs (Section 2) and (2) find a theoretical framework to establish RGEs' liability in international law (Section 3). In the search for a theoretical framework, it will be demonstrated that the law of international responsibility in its current shape is hard to seamlessly apply to RGEs (Section 3.1). Therefore, this paper argues for a new way to establish RGEs' liability based on Louis Henkin's theory of 'constitutional international law' (Section 3.2) and then envisages possible mechanisms under domestic and international law to enforce the liability of RGEs (Section 4).

Before going into detailed analysis, it is necessary to clarify the terminology that will be used in this paper.'Responsibility' and 'liability' are synonymous in many languages, and this paper does not stress any inherent philosophical or linguistic distinction between them. In accordance with their common usage in international law discourse, the'law of international responsibility'refers to the whole branch of international norms and principles that deal with the responsibility of different actors in the international legal system. Given the ILC's work under the topics of 'State Responsibility' and 'International Liability for Injurious Consequences arising out of Acts Not Prohibited by International Law', the terms'State responsibility' and 'strict liability' ${ }^{20}$ in this paper denote the meanings defined under the respective ILC topics. This author prefers the term 'liability' for RGEs to emphasise both that monetary compensation is the intended form of responsibility ${ }^{21}$ and that the rationale underlying RGEs' liability is more analogous to strict liability than State responsibility.

\section{Identifying RGEs: a difficult task}

The first step in the project of establishing and enforcing the liability of RGEs is to identify who are RGEs. As far as this author's research has revealed, existing studies simply presume the origin States as RGEs and focus on their responsibility without exploring whether non-State actors could also be RGEs. ${ }^{22}$ This author contends that both non-State actors and the origin States can be RGEs given how the concept of refugee is interpreted in contemporary international law.

There are different legal definitions of refugee in international law. ${ }^{23}$ Considering that the 1951 Convention 'remains the sole, legally binding, international instrument providing specific protection to refugees, ${ }^{24}$ this paper limits its discussion of the liability of RGEs to Convention refugees. Revised by Article 1 of the 1967 Protocol, Article 1(A)(2) of the 1951 Convention defines a Convention refugee as any person:

owing to well-founded fear of being persecuted for reasons of race, religion, nationality, membership of a particular social group or political opinion, is outside the country of his nationality and is unable or, owing to such fear, is unwilling to avail himself of the protection of that country; or who, not having a nationality and being outside the country of his former habitual residence as a result of such events, is unable or, owing to such fear, is unwilling to return to it.

\subsection{State-centered paradigm and the interpretation of refugee definition}

Convention refugee definition is premised on two fundamental concepts: persecution and protection. According to Article 1(A)(2), a refugee is someone who has a well-founded fear of persecution and cannot find sufficient protection in the country of origin. The precise meaning of 'persecution' and 'protection' is, however, nowhere defined in the 1951 Convention. Since 'international law [...] has always been peculiarly susceptible to the tyranny of phrases',25 the interpretation of key phrases in the refugee definition has always been subject to controversies. ${ }^{26}$

One interpretive controversy regards who can persecute and protect individuals under the 1951 Convention. In the early years, the interpretation of the Convention refugee definition was premised on a strict State-centered paradigm in which States are presumed to (1) be the only agent of persecution ${ }^{27}$ and protection; ${ }^{28}$ and (2) have effective control over the whole territory. ${ }^{29}$ Under this State-centered paradigm, the qualifications of refugee status were simplified to the only scenario of 'monolithic aggressor State ${ }^{\prime 30}$ persecuting its people.

20 The term 'strict liability' (as opposed to 'international liability') is used to correspond to the ILC work under 'International Liability for Injurious Consequences arising out of Acts Not Prohibited by International Law' because (1) strict liability captures the essence of relevant ILC rules and (2) the ILC's work under this topic only covers strict liability regarding transboundary damage from hazardous activities rather than laying out the general rules regarding all kinds of international liability.

21 Certain understanding of liability construes it as a form of responsibility narrowly defined to stress the 'obligation to pay compensation or make reparation for injuries', Sompong Sucharitkul, 'State Responsibility and International Liability under International Law' (1996) 18 Loyola of Los Angeles International and Comparative Law Review 821 at 822.

22 See Jennings, supra note 5; Tomuschat, supra note 7; Akhavan \& Bergsmo, supra note 7; Giustiniani, supra note 15; Hofmann, supra note 8.

23 See Guy S. Goodwin-Gill \& Jane McAdam, The Refugee in International Law, 3rd edn (Oxford University Press, 2007 ) at 15-41.

24 Jean-Yves Carlier, 'The Geneva Refugee Definition and the "Theory of the Three Scale"', in Frances Nicholson and Patrick Twomey (eds.), Refugee Rights and Realities: Evolving International Concepts and Regimes (Cambridge University Press, 1999) at 37.

25 J. L. Brierly, 'Matters of Domestic Jurisdiction' (1925) 6 British Yearbook of International Law 8 at 8.

26 Daniel J. Steinbock, 'The Refugee Definition as Law: Issues of Interpretation', in Frances Nicholson \& Patrick Twomey (eds.), Refugee Rights and

Realities: Evolving International Concepts and Regimes (Cambridge University Press, 1999) 13 at 14.

27 Catherine Phuong, 'Persecution by Non-state Agents: Comparative Judicial Interpretations of the 1951 Refugee Convention' (2002) 4 European Journal of Migration and Law 521 at 522.

28 See Section 2.4, below.

29 UNHCR, Guidelines on International Protection: 'Internal Flight or Relocation Alternative' within the Context of Article 1A(2) of the 1951 Convention and/or 1967 Protocol relating to the Status of Refugees, UN doc HCR/GIP/03/04 (2003) at para 7 ('National authorities are presumed to act throughout the country').

30 James C Hathaway \& Michelle Foster, 'Internal Protection/Relocation/Flight Alternative as an Aspect of Refugee Status Determination', in 
Subsequent practice under the 1951 Convention has witnessed the loosening of this strict State-centered paradigm, as 'fragmented State power' ${ }^{\prime 31}$ has become an international reality in recent decades. According to Eeva Nykänen, ' $[\mathrm{t}]$ he nation state is no longer the sole holder of the relevant power, but instead various non-state actors [among a wide spectrum] have become increasingly significant in this regard' ${ }^{32} \mathrm{As}$ a response, the State-centered paradigm in the interpretation of the refugee definition has been loosened to (1) generally accept non-State persecution and (2) start to acknowledge non-State actors as a qualified source of protection to a certain extent. The following analysis will first identify RGEs under the strict State-centered paradigm and then proceed to scenarios that involve non-State persecution and non-State protection.

\subsection{States as RGEs: strict State-centered paradigm}

Under the strict State-centered paradigm of the refugee definition, States are RGEs. When States are the only actors of both persecution and protection in refugee law, the lack of protection is demonstrated by the very fact of persecution - one cannot expect the availability of State protection when the State itself is the persecutor. Therefore, in practice 'a well-founded fear of Convention-relevant persecution - provided that no exclusion provisions applied - was [generally treated as] the only criterion for recognition of refugee status ${ }^{\prime 33}$ prior to the late 1970 s when the State-centered paradigm dominated the interpretation of international refugee law, and the precise meaning of protection in the refugee definition was not much discussed.

\subsection{Loosening the State-centered paradigm (I): identifying RGEs in non-State persecution}

\subsubsection{Non-State persecution and the lack of State protection}

The concept of non-State persecution emerged around the 1980s to ask if international refugee law had evolved to a point to accept non-State actors as the agents of persecution. Although the 1951 Convention is silent about non-State persecution and previous State practice regarded States as the exclusive actors of persecution, non-State persecution has been accepted in the subsequent agreements and practice of many contracting parties. ${ }^{34} \mathrm{After}$ a period of debates over how to define persecution from non-State actors, ${ }^{35}$ the definition of non-State persecution has generally been settled.

Nowadays, non-State persecution is usually defined as serious harm (i.e. severe violation of human rights) carried out by non-State actors that the State is unable or unwilling to protect the victim from. ${ }^{36}$ By definition, the existence of nonState persecution entails a lack of State protection. Only when the State is unable or unwilling to protect can the victim be said to have a well-founded fear of being persecuted by non-State actors. ${ }^{37}$

\subsubsection{Identifying RGEs in non-State persecution}

To identify RGEs in cases of non-State persecution is more complicated because non-State persecution is defined by both the harm from non-State actors and the State's lack of protection. When the actor of harm and that of protection no longer overlap, who should be identified as an RGE: the non-State persecutor (the actor of harm), the State (the actor of failed protection) or both? This question requires a deeper look at the conceptual underpinnings of RGEs.

For the purpose of this paper, the aim of identifying RGEs is to further establish and enforce their liability under international law. Therefore, two components of liability are important for the conceptualisation of RGEs: causation and blameworthiness. The element of causation is clearly implicated in the word 'generate' which means to 'cause, give rise to.38 As Michael Moore noted, '[c]ausation matters to legal liability,',39 and causation 'in the context of attributing responsibility [...] refers to a natural relation that holds between events or states of affairs.'40 In non-State persecution, both non-State persecutor and State satisfy this causation requirement, because both the events of non-State persecution and the State's lack of protection are indispensable in defining non-State persecution.

Blameworthiness is also significant for the identification of RGEs because causation is not always a sufficient condition for liability in the realm of law. In domestic law, for example, '[p]eople are not necessarily blamed for the bad things

Erika Feller, Volker Türk \& Frances Nicholson (eds.), Refugee Protection in International Law: UNHCR's Global Consultations on International Protection (Cambridge University Press, 2003) 357 at 360.

31 Eeva Nykänen, Fragmented State Power and Forced Migration (Martinus Nijhoff Publishers, 2012).

32 Ibid at 1.

33 Jessica Schultz \& Terje Einarsen, 'The Right to Refugee Status and the Internal Protection Alternative: What does the Law Say?' in Bruce Burson \& David James Cantor (eds.), Human Rights and the Refugee Definition: Comparative Legal Practice and Theory (Brill Nijhoff, 2016$) 274$ at 277.

34 See Andreas Zimmermann (ed.), The 1951 Convention Relating to the Status of Refugees and its 1967 Protocol: A Commentary (Oxford University Press, 2011) at 365-367.

35 For the debates about different approaches to the interpretation and application of non-State persecution, see: Phuong, supra note 27; Walter Kälin, 'Non-State Agents of Persecution and the Inability of the State to Protect' (2001) 15 Georgetown Immigration Law Journal at $415-431$.

36 See e.g. EU Qualification Directive, art. 6(c); Migration Act 1958 (Australia) section 5LA; Hathaway \& Foster, supra note 11 at 292-297;

Zimmermann, supra note 34 at 367-369.

37 Hathaway \& Foster, supra note 11 at 293.

38 'Generate' in Oxford English Dictionary (www.oed.com, last visited 18 March 2018).

39 Michael S. Moore, Causation and Responsibility: An Essay in Law, Morals, and Metaphysics (Oxford University Press, 2009 ) at 3.

$40 \quad$ lbid at 5 . 
they cause', which means that 'blameworthiness involves more than cause and effect.'.1 In the context of liability for refugee-generating, the persecutor - both State and non-State actor of persecution - is of course blameworthy. But it might be reasonably argued that the State is not to blame when it is willing yet unable to protect the individual from non-State persecutors.

In non-State persecution, the blameworthiness of States is easy to establish when they are unwilling to protect the individual from non-State persecution. ${ }^{42}$ Unwillingness to protect makes the State complicit in or an enabler of persecution and therefore blameworthy for refugee-generating, when the State itself is unequivocally responsible for the infliction of serious harm,',central government encourages or condones persecution carried out by subordinate or localized arms of the government' or 'the State [tolerates or tacitly encourages non-State persecution] despite clear ability to intervene. ${ }^{\prime 3}$

But is the State blameworthy when it is willing yet unable to protect? The scenario of 'willing yet unable to protect' means that ' $\mathrm{t}$ ] he State does not condone persecutory measures carried out by non-State agents but is unable to provide protection against them' ${ }^{\prime 4}$ The State's inability to protect may or may not involve its government having lost effective control over parts or the entirety of the territory.

When the State is willing yet unable to protect the individual from non-State persecution, blameworthiness of the State in refugee-generating is clearly susceptible to disagreements. Since' $[\mathrm{t}$ ] o be blameworthy, one must have made a choice to engage in conduct which causes an undesirable outcome' and '[t]he relevant choice only exists if the [actor] could have conducted themselves so as to avoid the undesirable outcome, ${ }^{\prime 5}$ the incapacity of States to protect makes it seem unduly harsh to blame States for refugee-generating especially when they have shown their 'best efforts' (yet still failed) to protect. ${ }^{46}$ But on the other hand, not identifying States as RGEs might in practice lead to the problematic trend of giving States an easy pass, considering that States can always claim they are unable to protect and that the precise line between unwillingness and inability to protect is often hard to draw in practice.

In sum, non-State persecutors are always identified as RGEs. States are also identified as RGEs when they are unwilling to protect. But it is controversial as to whether States should be identified as RGEs when they are willing yet unable to protect the individual from non-State persecution.

In conclusion, in cases of non-State persecution: (1) the non-State persecutor is always an RGE; (2) a State is an RGE when it is unwilling to protect individuals from the real risks of non-State persecution; (3) it is inconclusive if the State is an RGE when it is willing yet unable to protect individuals from the real risk of non-State persecution.

\subsection{Loosen the State-centered paradigm (II): identifying RGEs when non-State protection is acknowledged}

\subsubsection{The recognition of non-State actors of protection}

While the loosening of the State-centered interpretive paradigm to include non-State persecution for the purpose of refugee status determinations (RSD) has been generally accepted, the discussion is rather scant as to the acceptance of non-State protection. ${ }^{47}$ The reality in many top origin countries of refugee flows is that State protection is not available in a considerable portion of the territory simply because the central government has lost effective control over these areas. $^{48}$

In light of the reality, it does not seem unreasonable to extend the source of protection to non-State actors at least in the areas under effective control of non-State actors. The EU Qualification Directive, for example, has formally recognised non-State entities as the actors of protection ${ }^{49}$ for the purpose of RSD under Article 7.

Although the inclusion of non-State entities as actors of protection has led to many criticisms, ${ }^{50}$ there has been emerging international practice to recognise non-State protection provided that non-State actors indeed provide true efficient and durable ${ }^{\prime 51}$ protection. Such durable and effective non-State protection is most likely to exist when the non-State entities have gained the de facto status of 'stable quasi-State authorities who control a clearly defined

41 Glenn Shafer, 'Causality and Responsibility' (2001) 22 Cardozo Law Journal 1811 at 1819.

42 See Hofmann, supra note 8 at 702.

43 Hathaway \& Foster, supra note 11 at 297-298.

44 Kälin, supra note 35 at 416.

45 James Goudkamp, 'The Spurious Relationship between Moral Blameworthiness and Liability for Negligence' (2004) 28 Melbourne University Law Review 342 at 347.

46 Hathaway \& Foster, supra note 11 at 313-315 (demonstrating that States can be unable to protect individuals from non-State persecution even though 'best efforts' to protect have been provided).

$47 \quad$ Nykänen, supra note 31 at 196.

48 See UNHCR Eligibility Guidelines for Assessing the International Protection Needs of Asylum-Seekers from Afghanistan, 19 April 2016, UN doc HCR/ EG/AFG/16/02 at 10, 14, 18; International Protection Considerations with Regard to People Fleeing Southern and Central Somalia, January 2014, UN doc $\mathrm{HCR} / \mathrm{PC} / \mathrm{SOM} / 14 / 01$ at 12-15; International Protection Considerations with Regard to People Fleeing the Syrian Arab Republic (Update V), November 2017, UN doc HCR/PC/SYR/17/01 at 5, 8-9.

49 EU Qualification Directive, art. 7.

50 See e.g. ECRE Information Note on the Directive 2011/95/EU of the European Parliament and of the Council of 13 December 2011 at 6-7, available at www.refworld.org/docid/551922ae4.html (last visited 21 March 2018).

51 Nykänen, supra note 31 at 200. 
territory of significant size and stability, and who are able and willing to give effect to rights and to protect an individual from harm in a manner similar to an internationally recognised State..52 Under Article 7 of the EU Qualification Directive, 'parties or organisations, including international organisations' may qualify as non-State actors of protection when they are 'controlling the State or a substantial part of the territory of the State'.

\subsubsection{Non-State actors of protection as RGEs?}

With the extension of actors of protection to non-State entities, a difficult question arises: whether non-State actors of protection can be identified as RGEs when they fail to protect individuals from persecution. Since States (as actors of protection) are identified as RGEs at least when they are unwilling to protect, should the same rationale apply to nonState actors of protection?

Again, arguments can be made on both sides about the blameworthiness of non-State actors of protection. The key point of disagreement is whether the distinction between State and non-State actors matters for international law to place blame in the form of liability. Although qualified protection in a certain part of territory may be provided by both States and non-State actors, it does not necessarily entail that international law holds both to the same standards of blameworthiness.

It might be argued that the blameworthiness threshold for States is lower because States' obligations to protect are premised on their privileged position as the sole holders of sovereignty. Without a corresponding power to exercise 'the exclusive competence [...] in regard to its own territory,',3 it could be argued that non-State actors' responsibility to protect is also lower than that of States. It might also be questioned if non-State actors are bound by international refugee law in the first place. Therefore, it cannot be definitely concluded whether non-State actors of protection can be identified as RGEs.

\subsection{Interim conclusion}

In sum, the identification of RGEs can be summarised as follows:

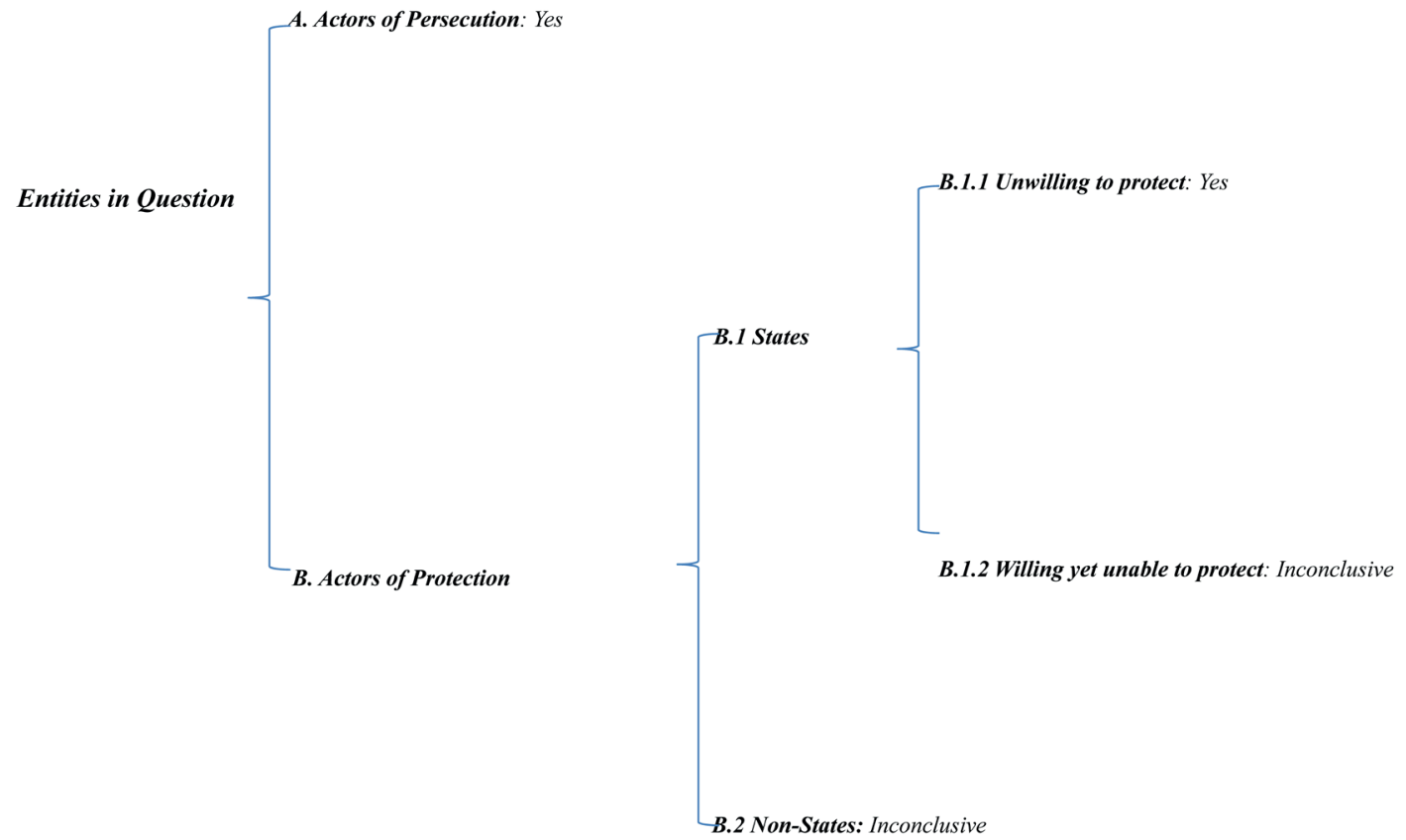

For categories B.1.2 and B.2 where international refugee law is inconclusive about whether the entity in question is an $\mathrm{RGE}$, the discretion lies with decision-makers themselves, such as the receiving States.

\section{Establishing the liability of RGEs in international law}

Now that RGEs have been identified, this section aims to find a theoretical framework to establish the liability of these entities in international law for refugee-generating. The following analysis will demonstrate that the law of international responsibility in its current shape, which includes the frameworks of State responsibility and strict liability, cannot

52 European Commission, Proposal for a Council Directive on minimum standards for the qualification and status of third country nationals and stateless persons as refugees or as persons who otherwise need international protection, OJ 2002 C 51 E/325, art. 9(3).

53 Island of Palmas Case, Reports of International Arbitral Awards, vol. II at 838. 
apply to RGEs seamlessly due to various legal obstacles. Therefore, this paper turns to another theoretical framework based on Louis Henkin's theory of 'constitutional international law' to establish RGEs' liability.

Since the aim of this section is to establish RGEs' liability, a preliminary question asks to whom RGEs are liable to pay compensation. Although commentators have previously envisaged State responsibility for refugee-generating against individual refugees, ${ }^{54}$ the receiving States ${ }^{55}$ and the international community as a whole ${ }^{56}$ this paper focuses solely on the liability of RGEs against the receiving States for two reasons. First, in terms of practicality, the receiving States are more resourceful, and therefore more likely than individual refugees ${ }^{57}$ and the 'international community as a whole' to find actual methods to enforce the liability of RGEs. Second, providing receiving States with a 'right' ${ }^{\prime 58}$ or 'cause of action $^{159}$ for compensation against RGEs is central to restoring the operational workability of international refugee protection. Receiving States will be more likely to maintain commitment to international refugee protection when they are equipped with a legal mean to seek monetary compensation from RGEs and use it in 'providing [refugees] with a humane life.60

\subsection{Liability of refugee-generating: the normative lacuna in the law of international responsibility}

\subsubsection{Lack of rules of international responsibility to non-State actors}

In accordance with the identification of RGEs, ${ }^{61}$ both States and non-State actors can be RGEs. The role of non-State actors in refugee-generating cannot be underestimated, ${ }^{62}$ but concrete rules are generally lacking in the law of international responsibility de lege lata to establish the responsibility of non-State actors.

As James Crawford noted, 'State responsibility is [still] the paradigm form of responsibility on the international plane.63 While the law of international responsibility has also extended to international organisations, 'it is doubtful whether any general regime of responsibility has developed to cover [other non-State actors] ${ }^{64}$ Therefore, the law of international responsibility in its current form is not capable of establishing the responsibility of non-State RGEs except for international organisations. However, non-State RGEs are usually entities other than international organisations, such as clans, militias, armed groups and terrorist groups. The liability of these non-State RGEs clearly goes beyond the scope of the law of international responsibility de lege lata.

\subsubsection{Obstacles of applying State responsibility or strict liability to States for refugee-generating}

After finding that the law of international responsibility is generally unable to establish the liability of non-State RGEs, we now turn to see if States'liability for refugee-generating can be established by the law of international responsibility. The law of international responsibility 'has been largely articulated through the work of ILC'65 which has provided two frameworks - State responsibility and strict liability. For the purpose of this paper, we refer to the ILC Draft Articles on Responsibility of States for Internationally Wrongful Acts ${ }^{66}$ ('Draft Articles on State Responsibility') for the framework of State responsibility and the Draft Principles on the Allocation of Loss in the case of Transboundary Harm arising out of Hazardous Activities ${ }^{67}$ ('Draft Principles on the Allocation of Loss') for the framework of strict liability. The following analysis demonstrates that neither framework can apply seamlessly to establish the liability of State RGEs.

\subsubsection{Obstacles of applying State responsibility}

In order to establish State responsibility for refugee-generating, there must be an internationally wrongful act of the origin States. ${ }^{68}$ An action or omission constitutes an internationally wrongful act when it (1) is attributable to the State under international law and (2) constitutes a breach of an international obligation of the State. ${ }^{69}$ Even when State responsibility for refugee-generating has been established, the receiving State must qualify as an injured State so

54 Tomuschat, supra note 7 at 60-71; Giustiniani, supra note 15 at 176-208; Luke T. Lee, 'The Right to Compensation: Refugees and Countries of Asylum' (1986) American Journal of International Law 532 at 537-552.

55 Tomuschat, supra note 7 at 71-77; Lee, supra note 56 at 552-564.

56 Tomuschat, supra note 7 at $77-78$.

57 See Lee, supra note 56 at 537-538.

58 Lee, supra note 56; Hannah R. Garry, 'The Right to Compensation and Refugee Flows: A “Preventative Mechanism” in International Law?' (1998) 10 International Journal of Refugee Law 97.

59 Garry, supra note 60 at 101.

60 Goodwin-Gill \& Sazak, supra note 9.

61 See Section 2, above.

62 Kälin, supra note 35 at 415.

63 James Crawford, 'The System of International Responsibility' in James Crawford, Alain Pellet \& Simon Olleson (eds.), The Law of International Responsibility (Oxford University Press, 2010) at 17.

64 Ibid at 18.

65 James Crawford, Brownlie's Principles of Public International Law, 8th edn (Oxford University Press, 2012 ) at 539.

66 Adopted by the ILC in 2001, available at http://legal.un.org/docs/?path=../ilc/texts/instruments/english/draft_articles/9_6_2001.pdf\&lang=EF (last visited 1 April 2018).

67 Adopted by the ILC in 2006, http://legal.un.org/docs/?path=../ilc/texts/instruments/english/draft_articles/9_10_2006.pdf\&lang=EF (last visited 1 April 2018).

68 Draft Articles on State Responsibility, art. 1 ('Every internationally wrongful act of a State entails the international responsibility of that State'). 69 Ibid, art. 2. 
as to invoke the responsibility of State RGEs. ${ }^{70}$ As this author has repeatedly emphasised, monetary compensation is the intended form of RGEs' liability because a right of monetary compensation for the receiving States is central to restoring the sustainable functioning of international refugee protection.

Identifying the breach of international obligation is the key step in establishing State responsibility, because only after the breach of 'primary' rules of international law is pinpointed can the 'secondary' rules of State responsibility be applied to see if the breach is attributable to the State and what legal consequences it may incur. Surprising as it may seem, there is no general rule in international law that prohibits States from generating refugees. ${ }^{71}$ Since refugeegenerating per se is not a breach of international obligation, we need to look elsewhere for the breach of a primary rule of international law. So far, scholars have tried to base State responsibility for refugee-generating on two sets of primary rules - international human rights law and territorial sovereignty.

International Human Rights Law. Many commentators pointed out that States violate their obligations under international human rights law in refugee-generating..$^{72}$ Convention refugees must have a well-founded fear of persecution. Since persecution is now commonly understood as severe violation of human rights, it seems plausible to rely on international human rights law to establish State responsibility for refugee-generating.

Here two obstacles appear. First, while State persecution is attributable to a State, non-State persecution is usually not attributable to a State. ${ }^{73}$ Second, although many refugees may have experiences of past persecution, the refugee definition does not require actual persecution. All that is required is a well-founded fear of persecution. This has led some commentators to caution that the flight of single individuals generally does not suffice [to establish an internationally wrongful act], considering that it could be based on a mere, though well-founded, fear of persecution or other fundamental human rights violations, rather than concrete breaches [of international human rights law] ${ }^{74}$

Faced with these obstacles, can we argue that States have breached their international human rights obligations as long as some individual in their territory is at real risk (i.e. well-founded fear) of persecution regardless of the actors of persecution? The answer seems to be no. Although some human rights jurisprudence has grown to recognise States' positive human rights obligation to take measures to intervene 'at the time of the existence of a real and immediate risk to the life of an identified individual',75 the legal standard (such as the standard of 'immediate risk to the life') in such human rights jurisprudence is not applicable to the general scenario of refugee-generating. ${ }^{76}$

Territorial Sovereignty. In addition to international human rights law, commentators have also resorted to territorial sovereignty as a source of primary rules of international law in the attempts to establish State responsibility for refugeegenerating. ${ }^{77}$ Commentators generally refer to territorial sovereignty and sovereign equality to argue that refugeegenerating - especially when resulting in mass-influx - violates the sovereignty and territorial integrity of the receiving States. Many authors referred to receiving States' sovereignty/sovereign rights to exercise exclusive jurisdiction over their own territory and population ${ }^{78}$ and argued:

while in principle States have the sovereign right to decide who to admit in their territory, such a right would be seriously limited if a country were confronted with a mass flow of people who could not be refouled for legal or humanitarian grounds. ${ }^{79}$

Such a line of argument, however, is questionable in many respects. To start with, sovereignty might be too vague ${ }^{80}$ a concept to qualify as a concrete/specified source of international obligation that is required by Article 2(b) of the Draft Articles on State Responsibility. Since almost every breach of international obligation can be described as a certain violation of State sovereignty, it is reasonable to require a clear identification of what international obligation is breached rather than allowing for a general claim based on State sovereignty.

Second, although the territorial integrity of States is indeed a significant legal interest protected by international law, ${ }^{81}$ it is hardly plausible for the receiving States to characterise refugee admittance as a violation of their territorial integrity. Since 'territorial integrity, especially where coupled with political independence, is synonymous with territorial inviolability ${ }^{\prime 82}$ violations of territorial integrity usually involve the threat or use of physical violence against a State or the exercise of sovereign authority in the territory of a State without that State's consent.

$70 \quad$ Ibid, art. 42.

71 Giustiniani, supra note 15 at 174.

72 Akhavan \& Bergsmo, supra note 7 at 247-248; Tomuschat, supra note 7 at 72; Lee, supra note 56 at 538-543; Garry, supra note 60 at $107-109$.

73 Non-State persecution seems only attributable to a State when Article 8 of the Draft Articles on State Responsibility is applicable.

74 Giustiniani, supra note 15 at 174.

75 Osman v United Kingdom Application No 23452/94, Judgment of 28 October 1998, para 116.

76 See Franz Christian Ebert \& Romina I. Sijniensky, 'Preventing Violations of the Right to Life in the European and the Inter-American Human Rights Systems: From the Osman Test to a Coherent Doctrine on Risk Prevention?' (2015) 15 Human Rights Law Review 343 at 343.

77 Jennings, supra note 5 at 111-113; Hofmann, supra note 8 at 708; Garry, supra note 60 at 104-106; Lee, supra note 56 at 553-556; Tomuschat, supra note 7 at $71-72$; Giustiniani, supra note 15 at 175 .

78 Garry, supra note 60 at 104-105; Lee, supra note 56 at 553.

79 Giustiniani, supra note 15 at 175.

80 Louis Henkin, International Law: Politics and Values (Martinus Nijhoff, 1995) at 8.

81 UN Charter, art. 2(4).

82 LF Oppenheim, Oppenheim's International Law vol 2, 7th edn, H Lauterpacht (ed.) (Longman, 1952) at 154, cited in Samuel Blay, 'Territorial Integrity and Political Independence', in Max Planck Encyclopedia of Public International Law (last updated in March 2010, available at http://opil. ouplaw.com/home/EPIL) at para 6. 
By contrast, refugee admittance is a demonstration rather than a violation of the receiving State's consent. The international obligation to admit refugees comes from treaties (such as the 1951 Convention and the OAU Refugee Convention) created by the receiving States themselves. By ratifying or acceding to those treaties, the receiving States agree to admit refugees into their territory ${ }^{83}$ and transform such agreement into binding treaty obligations.

Even when the receiving State encounters more refugees at the border than it is willing and able to take, it is not to be presumed lightly that the refugees are admitted against the receiving State's consent or sovereign authority. Facing mass influx that goes beyond their capacity to accommodate, States have sovereign power to implement stricter border control or even close their borders. In fact, States are usually prepared to do so when a neighboring country becomes a source of refugee exodus. ${ }^{84}$ Therefore, it is hard to establish that the breach of territorial integrity is inherent in refugee-generating.

\subsubsection{Obstacles of applying strict liability}

While State responsibility is hard to establish for refugee-generating, many commentators turn to strict liability. As early as 1939 Jennings already referred to the sic utere tuo ut alienumnon laedas principle to argue that refugeegenerating policy 'constitutes not merely an inequitable act, but an actual illegality' in international law. ${ }^{85}$ The sic utere tuo ut alienumnon laedas principle was famously applied by the Trail Smelter arbitral tribunal. According to the tribunal:

under the principles of international law [...] no State has the right to use or permit the use of its territory in such a manner as to cause injury by fumes in or to the territory of another or the properties or persons therein, when the case is of serious consequence and the injury is established by clear and convincing evidence. ${ }^{86}$

This no harm rule from the Trail Smelter arbitration has subsequently been adopted in numerous instruments of international environmental law ${ }^{87}$ and led to the ILC's framework of strict liability'for activities involving risk of significant transboundary harm, which either is unforeseeable or, if foreseeable, is unpreventable even if a state takes due care.88 Principle 4 of the ILC Draft Principles on the Allocation of Loss stipulates 'prompt and adequate compensation'.

Some commentators have argued for applying the Trail Smelter principle to refugee-generating by analogy. ${ }^{89}$ Such an 'analogous application', however, has no sound basis in international law because the entire strict liability framework was developed within the context of international environmental law and has nothing to do with refugee-generating. Unlike the framework of State responsibility, strict liability is a framework of 'primary' rather than 'secondary' rules..$^{90}$ Therefore, rules of strict liability that deal with transboundary harm do not validate the applicability of strict liability to refugee-generating for the simple reason that refugees are not transboundary damage. ${ }^{91}$

\subsection{Establishing the liability of RGEs through Louis Henkin's theory of 'constitutional international law'}

Although the law of international responsibility is unable to establish RGEs' liability, the legitimacy of RGEs' liability for refugee-generating is almost commonsensical. Because of RGEs, refugees are forced to leave their country of origin and seek asylum in a foreign country which is under legally-binding international obligation to receive and protect refugees. Since 'the international community relies on individual [receiving] States to shoulder the primary responsibilities [of refugee protection]', the costs of refugee protection also 'sits on [the receiving State's] own balance sheet.'.92 It would be extremely unfair if RGEs did not have to bear the cost of refugee protection and the burden of refugee protection were shared only among the receiving States. Therefore, corrective justice is called upon to shift the emphasis on RGEs 'as part of the international burden-sharing regime [...] to alleviate the receiving States ${ }^{193}$ from the cost of refugee protection.

It is precisely based on this understanding of corrective justice that the analogy is made between refugees and transboundary harms. According to Luke Lee:

Refugees, of course, are not 'fumes'. Nevertheless, certain legal similarities exist: both may cross international boundaries from countries of origin; both such crossings are preventable by the

83 See the 1951 Convention, art. 31.

84 For example, a 2006 report by the Danish Refugee Council noted that 'the borders surrounding Syria are becoming increasingly closed' as the situation in Syria deteriorates. Danish Refugee Council, Closing Borders, Shifting Routes: Summary of Regional Migration Trend Middle East (May 2016) at 4-5.

85 Jennings, supra note 5 at 111-113.

86 Trail Smelter Case, Reports of International Arbitral Awards, vol III at 1965.

87 Jutta Brunnée, 'Sic utere tuo ut alienum non laedas' in Max Planck Encyclopedia of Public International Law (last updated in March 2010, available at http://opil.ouplaw.com/home/EPIL) at para 11.

88 Malgosia Fitzmaurice, 'International Responsibility and Liability' in Daniel Bodansky, Jutta Brunnée \& Ellen Heat (eds.), The Oxford Handbook of International Environmental Law (Oxford University Press, 2008) at 1022

89 Lee, supra note 56 at 553-555. See also discussions in Giustiniani, supra note 15 at 175-176; Garry, supra note 60 at 105.

90 Fitzmaurice, supra note 90 at 1022-1025.

91 Giustiniani, supra note 15 at 175.

92 Goodwin-Gill \& Sazak, supra note 9

93 Garry, supra note 60 at 106 (internal citations omitted). 
countries of origin; both such crossings are not made with the voluntary consent of the receiving States; and both such crossings may impose economic and social burdens upon the receiving States, for which the countries of origin will be responsible. ${ }^{94}$

Although the Trail Smelter principle cannot apply directly to refugee-generating, this author argues that Louis Henkin's theory of'constitutional international law' can legitimise - i.e. provide a legal basis for - RGEs'liability under international law.

Henkin's idea of constitutional international law was put forward in the context of classifying different types of nontreaty international law. He divided non-treaty international law into four categories by the difference in their legal nature: 'constitutional' law; 'basic' law; established customary law; and contemporary customary law. ${ }^{95}$ Traditional positivist understanding of international law regards State consent as the ultimate legal basis of every international rule. ${ }^{96}$ Henkin challenged such an over-simplified view by pointing out two categories of international law - constitutional international and basic international law - that are not created by State consent.

According to Henkin, '[t]he international system implies a number of assumptions and conceptions of axiomatic "constitutional" character'97 - they are defined as constitutional international law. Henkin provided the following examples of constitutional international law:

the concepts of State and government, territory, population; the equality of States, State autonomy and its implications, notably the requirement of State consent and the effectiveness of consent to bind the State; territorial integrity and inviolability and the impermeability of the State as an entity; the principle of pacta sunt servanda; the concept of nationality; perhaps also established norms of diplomatic intercourse..$^{98}$

Henkin clarified that constitutional international law is created by State consent via treaty or custom. ${ }^{99}$ Instead, constitutional international law is the ultimate and overarching theoretical premise upon which the entire normative system of international law that we know of today is based.

According to Henkin, constitutional international law includes the concept of State, State consent and its binding effect, and the principle of pacta sunt servanda. Only based on these 'axiomatic' concepts and presumptions can we justify treaty and custom as legitimate law-making mechanisms of binding international rules. Otherwise, how can one justify the bindingness of treaty or custom when the very concept of State and the binding effect of State consent are not presumed in the first place?

Just like in domestic legal systems, constitutional law's authority does not come from other domestic law, the authority - legality and legitimacy - of constitutional international law is inherent in the 'international system' itself so that ' $[\mathrm{t}] \mathrm{he}$ modern inter-State system inherited these principles [of constitutional international law] at birth; the basic assumptions of the system were in place.'100 Although Henkin's enumerations - such as the equality of States and territorial integrity - have been well-established rules of international law, Henkin's theory points to the axiomatic and implied binding nature of such rules. In other words, Henkin makes clear that the normative effect of the equality of States and territorial integrity - and any other rules of constitutional international law - does not depend upon any treaty or any product of State consent. Constitutional international law can be implied rules and does not need the validation of State consent via treaty or State practice. Therefore, Henkin's theory brings a new possibility of establishing RGEs' liability when such liability is neither spelled out in treaty nor prevalent in State practice. If we can derive RGEs' liability from an aspect of constitutional international law - even if RGEs' liability is not yet explicit in any treaty and still not prevalent in State practice - RGEs' liability can be established by extension of the binding effect of constitutional international law.

This author argues that territorial allocation is a fundamental aspect of constitutional international law. Since 'unlike domestic legal systems, the international legal system is essentially decentralized,'101 power and authority is allocated among the territorial units of States in the international system so that '[e]very State has the right to exercise jurisdiction over its territory and over all persons and things therein.'102 Therefore, population ('persons') is also territorially allocated so that each individual is territorially linked to one (or in some cases more than one) State. This territorial link is conceptualised as nationality, which is included in Henkin's enumerations of constitutional international law. ${ }^{103}$

This territorial link between individuals and their State of nationality is crucial to establishing the liability of RGEs vis-à-vis the receiving States. Under international human rights law every individual is entitled to protection against persecution. But individuals are not entitled to claim protection from any State, because human rights obligations of a State extend only 'to all individuals within its territory and subject to its jurisdiction'.104 In accordance with the territorial allocation of population, the State of nationality is the default protector of its citizens because 'everyone has the right

94 Lee, supra note 56 at 554

95 Henkin, supra note 82 at 31-38.

96 See e.g. Alexander Orakhelashvili, The Interpretation of Acts and Rules in Public International Law (Oxford University Press, 2008$)$ at 37.

97 Henkin, supra note 82 at 31.

98 Ibid.

99 Ibid at 31-32

100 Ibid.

101 Lung-Chu Chen, An Introduction to Contemporary International Law: A Policy-Oriented Perspective, 3rd edn (Oxford University Press, 2015$)$ at 10.

102 Draft Declaration on Rights and Duties of States, art. 2 (1949) Yearbook of the International Law Commission at 287.

103 Henkin, supra note 82 at 31.

104 International Covenant on Civil and Political Rights, 16 December 1966, 999 UNTS 171 (entered into force 23 March 1976 ), art. 2. 
to a nationality'105 and to 'return to his country [of nationality]'.106 In contrast, under normal circumstances, individuals do not have a right to enter and stay in a foreign State without the permission of said State.

For each specific individual, constitutional international law has allocated the duty of protection and thus the financial burden attached to the country of nationality by default. Such a territorial allocation of the duty and financial burden of protection has been incorporated into the contemporary understanding of sovereignty. According to Hans-Georg Dederer, State sovereignty has both the 'negative' and the 'positive' side. ${ }^{107}$ While the positive side of sovereignty grants 'the right of a State to exercise the functions of a State within its territory to the exclusion of all other States', the negative side requires 'the State's obligation to protect, within its territory, the rights of other States or of other subjects of public international law as far as it concerns their rights under public international law'. ${ }^{108}$

When it is established in constitutional international law that the duty and financial burden of protection is by default allocated to the individual's country of origin, RGEs' liability vis-à-vis the receiving States appears to be a reasonable corollary. Because of RGEs, refugees are forced to leave their default territorial unit of protection because sufficient protection is not available, and the duty and financial burden of protection is involuntarily transferred to the receiving States. This involuntary transfer of the duty of protection therefore establishes a right/cause of action to compensation for the receiving States against RGEs who need to pay for the financial costs of refugee protection.

It is worth emphasising that the receiving State's international obligations of refugee admittance and protection do not exempt RGEs' liability to pay, because the territorial transfer of protection duty is involuntary in nature for the receiving State. Unlike voluntary territorial transfer of protection duty, e.g. when the receiving State approves foreigners to enter and stay in its territory by issuing visas, the involuntary nature of refugee admittance is reflected in two significant aspects. First, the receiving State does not voluntarily choose the foreign individuals (i.e. refugees) to which protection duty is transferred. Second, the receiving State cannot voluntarily terminate the territorial transfer of protection duty by sending refugees back to their country of origin (i.e. the default territorial unit of protection) because of nonrefoulement obligations. Therefore, the financial burden of refugee protection is involuntarily imposed on the receiving States, and RGEs are liable to pay up as the generators of said financial burden.

\section{Possible mechanisms to enforce RGEs' liability: an outlook}

Now that the liability of RGEs is established in international law, it is imperative to explore possible mechanisms to enforce the liability. Since there is hardly any existing international practice of enforcing RGEs' liability, ${ }^{109}$ this paper neither attempts nor is able to give conclusive answers or a detailed blueprint of how RGEs' liability is to be enforced. Instead, this section provides a brief outlook on the possibility and feasibility of relying on existing legal and institutional structures in international and domestic law to enforce RGEs' liability.

\subsection{Possible international mechanisms}

If the liability of RGEs is to be enforced through an international mechanism, a top-down model is the most likely structure of enforcement - an international authority prescribes the liability of RGEs and the receiving States enforce the liability. At first glance, two existing international structures - the United Nations Security Council (UNSC) and the UNHCR - appear to be possible candidates as the international authority, but neither can find a general competence to enforce RGEs' liability under their current mandate.

The UNSC has the power to adopt legally binding decisions to the member States, but not every resolution of the UNSC is binding. Since 'the binding effect of [Security Council] resolutions belongs to the realm of international peace and security',110 the UNSC lacks the general 'legislative' authority over the matter of refugee-generating. Although one can argue that refugee-generating may adversely affect international peace and security, it would be a stretch to interpret refugee-generating per se as a threat or breach of peace. The UNSC's practice is not likely to support such an interpretation. ${ }^{11}$

Some commentators envisaged the UNHCR as the central actor in the enforcement of RGEs' liability. ${ }^{112}$ Luke Lee argued that the UN's right to claim monetary compensation is found in the advisory opinion of the International Court of Justice (ICJ) in Reparation for Injuries Suffered in the Service of the United Nations. ${ }^{113}$ However, contrary to Lee's arguments, this advisory opinion is not applicable to RGEs' liability because the factual scenarios in the advisory opinion differ substantially from those of refugee-generating. In the advisory opinion, the ICJ confirmed the UN's capacity to claim compensation 'concerned solely with the reparation of damage caused to the Organization when one of its agents

105 Universal Declaration of Human Rights, art. 15(1).

106 Ibid, art. 13(2).

107 Hans-Georg Dederer, "'Responsibility to Protect" and "Functional Sovereignty"' in Peter Hilpold (ed.), Responsibility to Protect: A New Paradigm of International Law? (Brill Nijhoff, 2014) 156 at 167-171.

108 Ibid at 169.

109 Giustiniani, supra note 15 at 176.

110 Marko Divac Öberg, 'The Legal Effects of Resolutions of the UN Security Council and General Assembly in the Jurisprudence of the ICJ' (2006)

16 European Journal of International Law 879 at 885.

111 See Tomuschat, supra note 7 at 77.

112 Ibid at 78; Lee, supra note 56 at 549-552; Sazak, supra note 10 at 310.

113 Lee, supra note 56 at 551. 
suffers injury at the same time.'114 Although one might argue that refugee protection is one of 'the interests of which [UN] is the guardian,',15 refugees are not agents of the UN. The reasoning in the advisory opinion is therefore not applicable.

It is also hard to derive a power to enforce RGEs' liability from the UNHCR's mandate. Although the UNHCR has implied power 'which would [...] be required for the effective performance of [its] functions', 116 its implied power cannot go beyond the authority of the UN General Assembly because the UNHCR was 'established under the [General Assembly] as its subsidiary organ'.17 Since the General Assembly does not have the enforcement power of international law, the power to enforce RGEs' liability cannot be assumed for the UNHCR.

\subsection{Possible domestic mechanisms}

Since the top-down enforcement model centered upon international mechanisms does not appear plausible and practical, we need to turn to domestic mechanisms to enforce RGEs' liability. This author contends that domestic mechanisms based on the receiving State's own initiative and municipal law - a self-help model - are the mostly likely means to successfully enforce RGEs' liability given the current shape of international law.

The goal of domestic mechanisms is to enable the receiving States to obtain 'actual money', i.e. tangible forms of compensation, from RGEs and use this money in domestic refugee protection. Although some scholars have envisaged economic sanctions to be employed as a possible means of enforcement, ${ }^{118}$ most economic sanctions would not lead to tangible forms of compensation for the receiving States. ${ }^{119}$

For the receiving States, the most realistic means to enforce RGEs' liability might be to freeze and use the assets of RGEs in their own territory. The receiving States have the sovereign authority and capacity to track and freeze assets in their territory. Asset freezing has been used by States as a way to enforce international law with respect to some other subject matters such as combating terrorism ${ }^{120}$ and 'promoting human rights abroad.'121 There is no plausible reason why asset freezing cannot be used to enforce RGEs' liability. In light of the current refugee 'crisis', the receiving States might be incentivised to embrace the idea of seizing assets from RGEs since some of them have already tried to seize assets from refugees to cover the cost of refugee protection. ${ }^{122}$ Having asset freezing as a strategy to counter refugeegenerating while alleviating domestic financial burden in refugee protection may also help bring solidarity in domestic politics and depoliticise refugee problems.

For the receiving States to enforce RGEs' liability, the first step is to identify who are RGEs. Identifying RGEs can be a difficult task. Controversial questions such as 'are non-State actors of protection RGEs' and 'are States RGEs when they are willing yet unable to protect individuals from non-State persecution' call for decisions, and the decisions should be made by the receiving States themselves for accountability considerations.

Freezing RGEs' assets is State action. Unlike asset freezes under binding UNSC resolutions, the receiving States have the right (instead of the obligation) to enforce RGEs' liability. Therefore, the receiving States have discretion to decide whether and to which RGEs asset freezes are implemented. In practice, the discretion of the receiving States might be exercised in an arbitrary or erroneous way. In the case of arbitrary or erroneous enforcement of RGEs' liability, the receiving States should be accountable for their decisions. This is precisely why a self-help model is arguably a better way to enforce RGEs'liability than a top-down model in which the receiving States act as the enforcing organs of a higher international authority. If the receiving States enforces RGEs' liability under the direction of an international authority UNHCR for example - an accountability lacuna might occur. In the cases of arbitrary or erroneous enforcement of RGEs' liability, the receiving States can evade accountability by arguing that their asset freezes are carried out under the direction of the UNHCR, and the accountability of the UNHCR under international law is generally questionable and at least hard to enforce. ${ }^{123}$

Of course, the danger of abusive or arbitrary enforcement of RGEs' liability needs to be sufficiently recognised when the receiving States are allowed to decide for themselves who are RGEs and when to enforce liability against them. Indeed, such danger of abusive or arbitrary enforcement is always present no matter who the decision maker is. Organs of international organisations such as the UNSC and the UNHCR are also not immune to potential criticisms of

\footnotetext{
114 Reparation for Injuries Suffered in the Service of the United Nations, Advisory Opinion of 11 April 1949 , ICJ Reports 1949 at 180.

115 Lee, supra note 56 at 551.

116 UNGA, Refugees and Stateless Persons: Report of the Secretary-General, 26 October 1949, UN doc A/C.3/527 at para 48.

117 UNHCR, Note on the Mandate of the High Commissioner for Refugees and His Office, October 2013, at 1, available at www.refworld.org/ docid/5268c9474.html (last visited 13 April 2018).

118 See e.g. Lee, supra note 56 at 563.

119 See Andreas Lowenfeld, International Economic Law (Oxford University Press, 2002) at 698, cited in Barry Carter, 'Economic Sanctions' in Max Planck Encyclopedia of Public International Law (last updated in April 2011, available at http://opil.ouplaw.com/home/EPIL) at para 3.

120 See Blocking Property and Prohibiting Transactions With Persons Who Commit, Threaten To Commit, or Support Terrorism, Executive Order 13224, 23 September 2001, Federal Register vol 66 no 186.

121 Evan J. Criddle, 'Humanitarian Financial Intervention' (2013) 24 European Journal of International Law 583 at 583.

122 'Switzerland Seizing Assets from Refugees to Cover Costs', The Guardian, 15 January 2016, available at www.theguardian.com/world/2016/ jan/15/switzerland-joins-denmark-in-seizing-assets-from-refugees-to-cover-costs (last visited 29 January 2019); 'Danish Parliament Approves Plan to Seize Assets from Refugees', The Guardian, 26 January 2016, available at www.theguardian.com/world/2016/jan/26/danish-parliament-approvesplan-to-seize-assets-from-refugees (last visited 29 January 2019).

123 See Maja Janmyr, 'Advancing UNHCR Accountability through the Law of International Responsibility', in Kristin Bergtora Sandvik \& Katja Lindskov Jacobsen (eds.), UNHCR and the Struggle for Accountability: Technology, Law and Results-Based Management (Routledge, 2016 ) at 59.
} 
erroneous or biased decision making if they are empowered with the task of identifying RGEs and enforcing liability against them.

\section{Concluding remarks}

It is imperative to find a plausible theoretical framework to establish RGEs' liability. In the realm of international law theory does not necessarily translate into practice. But new practice is hard to materialise when there is no plausible theory to justify its legality and legitimacy. Without an international legal theory upon which RGEs' liability can be convincingly established, the receiving States are likely to feel incentivised to initiate novel practice to enforce RGEs' liability due to the concern that such novel practice might not find support in international law.

As scholars have noted, the unprecedented refugee crisis of the current time requires novel legal solutions. ${ }^{124}$ Enforcement of RGEs' liability by the receiving States would certainly be one novel legal solution to help restore the sustainable functioning of international refugee protection by 'discourage[ing] countries of origin from creating refugees, and encourag[ing] host countries to welcome them.'125 Therefore, for a helpful new practice to materialise, we need a plausible theory to justify it.

The relation between theory and practice is not a one-way street. Not only does practice find strength in theory, new practice can also shed light on theory by illuminating unexplored territories for existing theories to extend their scope of applicability and by encouraging the new theories to develop. Due to the normative lacuna in the law of international responsibility, this paper establishes RGEs' liability upon the theoretical framework of constitutional international law. Since RGEs' liability is derived from the involuntary territorial transfers of protection duty from the origin country to the receiving State, constitutional international law arguably only justifies the receiving State A's enforcement of the liability against those RGEs whose victim has been admitted and protected in State A. If RGE $\mathrm{x}$ has a foreign asset in State A yet no refugee generated by RGE x has come to State A, then State A's asset freeze of RGE x cannot be justified by constitutional international law.

State practice, however, can go beyond this theoretical limit of constitutional international law to progressively develop new international norms. For example, if more and more States start to enforce the liability against RGEs even when refugees generated by them have not come to these States (e.g. State A starts to freeze assets of RGE X for refugeegenerating), sufficiently widespread State practice and opinio juris can result in a norm of customary international law that announces refugee-generating as a violation of international law, and the prohibition of refugee-generating can be identified as an obligation erga omnes. The erga omnes prohibition of refugee-generating may provide new theoretical grounds to justify a 'universal jurisdiction' to enforce the liability of RGEs even if there is no additional link between RGEs and the receiving State.

It should be stressed, however, that this author does not intend to propose the enforcement of RGEs' liability as the solution to all refugee problems. It is not a cure-all for the refugee 'crisis', nor should it replace or be exploited as an excuse to circumvent the receiving States' international obligation to protect refugees. The receiving States should be allowed to claim monetary compensation against RGEs. But this should not mean that refugee protection becomes a quid pro quo for monetary compensation. With or without actual enforcement against RGEs' liability, the receiving State's international obligation of refugee protection remains the same.

124 See James Simeon, 'A New Protection Orientation and Framework for Refugees and Other Forced Migrants' (2017) 6:4 Laws 1; Joseph Blocher \& Mitu Gulati, 'Competing for Refugees: A Market-Based Solution to a Humanitarian Crisis' (2016) 48 Columbia Human Rights Law Review 53.

125 Blocher \& Gulati, supra note 126 at 53. 